\title{
Erik De Bom (red.), Europese gedachten
}

\author{
Bertjan Wolthuis
}

Erik De Bom (red.), Europese gedachten. Beschouwingen over de toekomst van de Europese Unie, Kalmthout: Pelckmans-Klement, 2014, 248 p.

Erik De Bom wil met de bundel Europese gedachten de aandacht van de politieke theorie vestigen op de Europese Unie. Dat is volgens hem nodig: het aandeel van de politieke theorie in de Europese studies is vooralsnog beperkt en eenzijdig. En dat is ook wenselijk: de Europese Unie wordt doorgaans beschreven en verklaard met behulp van empirische modellen; de politieke theorie zou met conceptuele verheldering en normatief onderzoek een waardevolle bijdrage aan de Europese studies kunnen leveren. De Bom hanteert hierbij de term politieke theorie in de breedst mogelijke zin; uit de bijdragen van de bundel blijkt dat ook rechtstheorie en politiek-economische theorie eronder vallen. In de Inleiding wordt een historisch overzicht van belangrijke publicaties over de EU gegeven. De Bom neemt in de laatste decennia een groeiende belangstelling voor normatieve vraagstukken waar. De bijdrage die theoretici leveren is volgens hem wel hoofdzakelijk op het legitimiteitsvraagstuk gericht, met als voornaamste strijdpunt het democratische gehalte van de EU. De Bom wenst een politieke theorie die zich minder bescheiden opstelt, één die 'inzichten kan bieden in de manier waarop de EU verder ontwikkeld kan en moet worden. Want hoe belangrijk de waarde van een democratisch en legitiem Europa op zich ook is, toch moet men een stap verder durven gaan en zich afvragen waarvoor dit democratisch en legitiem Europa dient' (p. 22).

De indeling van de bundel in vijf thema's (Onderbouw-Waarden-DemocratieRechtvaardigheid-Wereld) volgt wellicht een zekere logica, maar leidt ertoe dat stukken die inhoudelijk bij elkaar horen, niet bij elkaar zijn komen te staan. In deze bespreking groepeer ik ze gemakshalve wel op onderwerp.

Anya Topolski legt in haar bijdrage uit waarom ze bezorgd is dat het streven van de EU naar eenheid 'de ander' (p. 96) uitsluit. Dat dreigt te gebeuren, laat ze met inzichten van Hannah Arendt zien, zodra aan het lidmaatschap van de EU culturele of religieuze eisen worden gesteld. Topolski citeert hier Habermas, die in de Europese geschiedenis meent te hebben gezien dat 'het erfgoed van de op verlossing of emancipatie gerichte, joods-christelijke broederschapsethiek wat betreft het solidariteitsconcept een verbinding aangaat met het op juridisch-politieke vrijheid gerichte republikanisme van Romeinse herkomst'. Topolski verbindt dit staaltje van 'uitsluitingsretoriek' (p. 102) met de problematische relatie tussen de EU en Turkije, het land dat niet Europees genoeg is. Hoewel Topolski hier haastig redeneert, vraagt ze terecht aandacht voor het verschil tussen broederschap en vriendschap in de politiek. Waar broederschap op natuurlijke gelijkenissen wijst, kan vriendschap goed bestaan tussen mensen die sterk van elkaar verschillen. 
Topolski wil een Europese politiek die een 'maatschappij vormt en ondersteunt' en dat is uitdagender dan het mogelijk klinkt, want het houdt in dat Europese burgers en politici een open houding ten aanzien van de ander dienen aan te nemen en bereid zijn van de ander te leren.

Bij het thema van uitsluiting past ook De Boms bijdrage over de uitbreiding van de Europese Unie. Hij schrijft over het liberaal-nationalisme, een stroming die meent dat de natie onontbeerlijk is om de staat goed te laten functioneren. De natie (gemeenschappelijke waarden, geschiedenis, taal) is onontbeerlijk voor de ontplooiing van individuele autonomie, draagt via solidariteit bij aan het ondersteunen van verzorgingsstaatregimes en maakt democratische discussie mogelijk. Deze stroming kan dus verklaren waarom de EU zich voor een probleem gesteld ziet, voor zover de Unie meer is dan een intergouvernementele organisatie. Want zijn er wel Europese waarden? De uitbreidingspolitiek laat zien van wel: het Turkije-voorbeeld. De Bom wijst de liberale benadering af. Niet omdat ze stelt dat gedeelde waarden benodigd zijn, maar omdat ze die waarden begrijpt als 'prepolitiek' (p. 210). De Bom omarmt vervolgens Habermas' grondwetspatriottisme, volgens welke het prepolitieke alleen gebruikt mag worden om een specifiekere interpretatie van gemeenschappelijke politieke waarden te geven. Deze constitutionele identiteit zou vervolgens mogelijk moeten maken wat de natie volgens de nationaal-liberalen op het niveau van de staat kan betekenen. Dit constitutioneel patriottisme is specifiek genoeg om te verklaren waarom Turkije vermoedelijk geen lid zal worden (p. 215). Of deze uitsluiting verdedigbaar is, bespreekt De Bom niet. Het valt op dat De Bom niet verwijst naar de bijdrage van Topolski, die er wel nauw bij aansluit.

Stefan Rummens en Stefan Sottiaux leggen aan de hand van Carl Schmitts Verfassungslehre uit dat de EU het beste kan worden opgevat als een federatie van staten, een 'Bund'. De Bund bevindt zich tussen de 'Bundesstaat' (de federale staat) en de 'Staatenbund' (de confederatie) in. De federatie van staten is pluralistisch: zij vormt een autonome juridische en politieke orde, maar vervangt noch overtroeft daarbij die van de lidstaat. 'In een federatie blijven zowel de afzonderlijke lidstaten als het federale niveau drager van een soevereine autoriteit' (p. 42), terwijl bij een federale staat de soevereiniteit op het federale niveau ligt en bij de confederatie op het niveau van de lidstaten. Deze analyse impliceert volgens Rummens en Sottiaux, die hierbij naar eigen zeggen Habermas' Zur Verfassung Europas volgen, dat legitieme EU-besluitvorming moet worden teruggevoerd op de instemming van burgers en lidstaten, omdat de EU niet wil kiezen tussen federale staat en confederatie. In het licht hiervan is mij niet duidelijk geworden waarom de auteurs menen dat er toch moet worden gekozen. Rummens en Sottiaux vinden namelijk dat een 'congruentiebeginsel' noodzakelijk is, dat aangeeft in welk geval welke legitimeringsroute (via de burgers of via de lidstaten) voorrang moet krijgen. Stefan Van Hecke, Raf Geenens en Stefan Rummens werken verderop in de bundel nader uit hoe de legitimering van de EU via de burgers kan worden bevorderd. Volgens de auteurs is een Europees volk geen voorwaarde voor legitieme Europese politiek, wat soms wordt gedacht, maar is, omgekeerd, 
zichtbare Europese politiek een middel om een Europees publiek tot stand te brengen. De auteurs treden hier wederom in de voetstappen van Habermas.

In de bovenstaande bijdragen treedt al scherp naar voren dat normatieve posities nauw zijn verbonden met conceptuele analyses. Het begrip van wat de EU is, luidt de meetlat in waarlangs de Unie wordt gelegd en bereidt zo het oordeel voor over wat de EU zou moeten worden. Ronald Tinnevelt en Peter Bal onderkennen deze relatie tussen conceptuele analyse en normatieve theorie. Zij zien zelfs af van een eigen stellingname, om beter te kunnen laten zien 'op basis van welke criteria en opvattingen over de EU een antwoord wordt gegeven op de vraag naar de democratische legitimiteit' (p. 111). De conclusie die Tinnevelt en Bal trekken, ligt gezien dit vertrekpunt voor de hand: de verschillende formuleringen van het 'democratische tekort' waaraan de EU volgens sommigen zou lijden, zijn niet tot elkaar te herleiden, zodat er strikt genomen van verschillende democratische tekorten kan worden gesproken. Tinnevelt en Bal beëindigen de bijdrage met de interessante vraag of de noties van democratie, burgerschap en legitimiteit, ontwikkeld in de context van de natiestaat, misschien bijstelling behoeven om van toepassing te kunnen zijn op de EU. Niemand in de bundel pakt deze vraag overigens op.

Enkele bijdragen benaderen de Europese Unie vanuit het gezichtspunt van de sociale rechtvaardigheid. Helder De Schutter argumenteert voor een sterke en grote EU omdat een dergelijke EU voor een aanzienlijke herverdeling van welvaart zou kunnen zorgen. 'Net zoals bijvoorbeeld een verkleining van de cirkel van herverdeling doorgaans enkel bepleit wordt door wie welvarender is, zo wordt een grotere cirkel bepleit door wie herverdeling genegen is' (p. 61). De Schutter noemt de afwijzing van de EU door sommige socialistische Scandinavische partijen 'strategische niveaubepaling'. Hun keuze voor een beleidsniveau is niet ingegeven door ideologie, maar door 'de kans dat de ideologie wordt uitgevoerd' (p. 65) op dat niveau. 'Voor wie vindt dat herverdeling een rechtvaardigheidseis is, is het cruciaal om ervoor te zorgen dat er op Europees vlak herverdeling komt, en de huidige oppositie tegen een dergelijk plan is een obstakel dat herverdelers moeten overwinnen' (p. 66).

Een pragmatischer argument is dat de eurozone simpelweg te instabiel zal worden wanneer duidelijke winnaars en verliezers kunnen worden aangewezen. 'Sociale divergentie knaagt aan de legitimiteit van de huidige Europese samenwerking' (p. 155), aldus Frank Vandenbroucke. Een vorm van wederkerigheid is geboden waarbij sommige lidstaten structureel 'netto-gever' (p. 159) zijn, om de sociale problemen in andere lidstaten op te lossen. Het verlichte eigenbelang, dat volgens Habermas voldoende zou zijn, is volgens Vandenbroucke niet toereikend. Naast deze grondhouding van wederkerigheid moeten 'sociale investeringen' (p. 167) worden gepleegd. De auteur bepleit een Europese Sociale Unie. Het knappe daarbij is dat de bijdrage niet utopisch wordt, omdat Vandenbroucke steeds kiest voor een zakelijke, economische insteek en zijn betoog stevig onderbouwt. 
De conclusie is dat de bijdragen die in Europese gedachten staan, interessant zijn en degelijk. Een kritische lezer vindt misschien twee bezwaren. Het eerste is dat de bundel misschien niet de diversiteit en de onbescheidenheid toont, die de titel suggereert en waar de redacteur in de inleiding om vroeg. In veel bijdragen is legitimiteit en democratie toch het hoofdthema, de Europese Unie wordt over het algemeen positief benaderd en de auteurs leunen sterk op het oeuvre van Jürgen Habermas. Hiertegen kan worden aangevoerd dat sociale rechtvaardigheid ook een belangrijk thema is in de bundel en dat enkele auteurs de discussie waaraan Habermas bijdroeg, in hun bijdrage trachten verder te brengen. Het tweede bezwaar is dat de bundel wel een wat strengere compositie had verdiend. De bijdragen hebben meer met elkaar gemeen dan de auteurs willen toegeven en de indeling suggereert. 